\title{
Modularizing Emerging Technology Education: Two Case Studies
}

\section{Deb Newberry, Dakota County Technical College}

Deb Newberry is the director of the Nanoscience Technology program at Dakota County Technical College in Rosemount, MN where she created 8 college level nano specific courses and the 2 year, AAS degree Nanoscience Technologist program. Deb also is the Director/Principle Investigator of Nano-Link, a regional center for nanotechnology education which spans 5 states in the upper Midwest and is funded by the National Science Foundation.

Deb has a master's degree in nuclear physics with minors in chemical and mechanical engineering. She spent over 15 years as a researcher studying radiation effects on satellite systems. She developed methodologies for analysis and testing of radiation on satellite systems and has been involved with over 14 satellites currently on orbit. In 1991, she began work in the field of nanotechnology investigating the effect of radiation on composite materials using nanoparticles.

After 23 years of experience as a researcher and executive in the corporate world, she became a nanotechnology consultant and celebrated writer, coauthoring, The Next Big Thing is Really Small, a bestselling book on nanotechnology and is also the author of several chapters in nanotechnology and educational books. Deb has spoken to multiple organizations, including the U.S. Senate, IEEE, ASME, BIO, ATMAE, NCPN and others. A member of the editorial board of the Journal of Nano Education, she has published a number of articles in business magazines and professional journals.

\section{Dr. Marilyn Barger P.E., National Science Foundation ATE Centers}

Dr. Marilyn Barger is the Principal Investigator and Executive Director of FLATE, the Florida Regional Center of Advanced Technological Education, funded by the National Science Foundation and housed at Hillsborough Community College in Tampa, Florida since 2004. FLATE serves the state of Florida as its region and is involved in outreach and recruitment of students into technical career pathway; has produced award winning curriculum design and reform for secondary and post-secondary Career and Technical Education programs; and provides a variety of professional development for STEM and technical educators focused on advanced technologies. She earned a B.A. in Chemistry at Agnes Scott College and both a B.S. in Engineering Science and a Ph.D. in Civil Engineering (Environmental) from the University of South Florida, where her research focused on membrane separation science and technologies for water purification. She has over 20 years of experience in developing curricula for engineering and engineering technology for elementary, middle, high school, and post secondary institutions, including colleges of engineering. Dr. Barger serves on several national panels and advisory boards for technical programs, curriculum and workforce initiatives, including the National Association of Manufacturers Educators'Council. She is a Fellow of the American Society of Engineering Education, a member of Tau Beta Pi and Epsilon Pi Tau honor societies. She is a charter member of both the National Academy and the University of South Florida's Academy of Inventors. Dr. Barger holds a licensed patent and is a licensed Professional Engineer in Florida. 


\title{
Modularizing Emerging Technology Education: Two Case Studies
}

\author{
Deb Newberry, Dakota County Technical College \\ Marilyn Barger, Hillsborough Community College
}

\begin{abstract}
:
The rapid change in technology poses a challenge to the public, industry, educators and students. Formulation and creation of emerging concept content such as that associated with lean or advanced manufacturing, robotics, photonics, nanotechnology and biotechnology, in a modularized format enables the integration of new content into existing curricula. A modular or layered approach to content and its dissemination is based on surveys of over 300 high school and college science educators. These surveys queried educators with regard to desired characteristics of emerging technology content such as technical area, depth, supporting material etc. The survey results were used to create the module content and characteristics that would make integration of emerging content easier for educators. A modular approach can also be used to emphasize the same foundational math and science knowledge and skills in different courses in an applied technology context. This approach reinforces basic skills in a meaningful way.
\end{abstract}

Many types of modules (content, length, cost etc.) can be used at the secondary and postsecondary level with few changes. There are also a large number of STEM (science, technology, engineering and mathematics) courses at both levels that are appropriate for integration of modularized emerging technology content and/or STEM applications of technologies. Therefore, it can be challenging to find the best course or courses and the best sequence of topics to achieve maximum impact on student learning. One emerging technology (nanotechnology) curriculum modularization effort has reached over 6,000 students in secondary and postsecondary institutions. The design, development and implementation of various modular curricula in different courses and institutions is discussed.

This paper covers the initial implementation activities and the first cut of the results of these efforts. This information is applicable to educators and/or institutions which desire to disseminate emerging technology information or content. The positive results being received for the modular content and approach warrants and will receive additional research and analysis.

Introduction:

Post secondary educational institutions, particularly those involved in technician or technologist education are constantly required to introduce modified or new educational content. Educational institutions of this type often exist as the interface between education pedagogy, content and 
training and the imminent and emerging needs of high tech industries. Curriculum and program development is often the result of this direct relationship between industry needs and educational institution capabilities.

There are multiple approaches for introducing new content into the educational system. Historically, the rather tedious process of modified or new textbook generation has been the most often applied method. However, with the exponential change of technology - concepts may be outdated by the time a textbook is published and the pervasive use of electronic technology is eclipsing the ability of printed textbooks to remain up-to- date. Some of the various approaches for introducing new content include: on-line or hybrid courses, optional seminars, stackable courses, certificates or credentials, multi-entrance and exit career pathways and modularized or menu component programs. In addition to the delivery platform or format, there are a number of logistic issues required to be addressed when developing new content in any format including how big or how much material the units/modules should cover; what level of subject matter expertise is needed; level of the information to be covered; how to include activities for problembased learning; and knowing the target audience or audiences.

Typically, modular curricula contains content for anywhere between one and five days (1-5 hours) of lessons and activities.

The Audience and User Community:

No longer is "educational content" restricted to the traditional classroom. Television, museums and many social media are being used to convey educational material. As a result, the user audience has expanded from teachers and \{ four year college\} students to include students of all ages, in programs of varying duration as well as incumbent workers, employers looking for retraining or enhancement of employee skills and the general public. Each of these categories of users has varying requirements and restrictions on the created educational content. Integration of new science and engineering disciplines and concepts is especially challenging for educators where many programs are already saturated with required courses. Table 1 provides a matrix delineating some of the restrictions and requirements of the various user communities of new technology educational content. 


\begin{tabular}{|l|l|l|}
\hline User & Restrictions/Motivation & Needs/Requirements \\
\hline Educators - College & $\begin{array}{l}\text { Provide state of the art educational } \\
\text { content }- \text { often into specific } \\
\text { programs }\end{array}$ & $\begin{array}{l}\text { Technically sound content } \\
\text { Ready to use } \\
\text { Complete } \\
\text { Short Duration } \\
\text { Activity Driven }\end{array}$ \\
\hline $\begin{array}{l}\text { Educators - High } \\
\text { School }\end{array}$ & $\begin{array}{l}\text { Energize and excite students } \\
\text { Include new technology } \\
\text { Integrate content into traditional } \\
\text { courses }\end{array}$ & $\begin{array}{l}\text { Correlation to traditional courses } \\
\text { and content }\end{array}$ \\
\hline Industry & $\begin{array}{l}\text { Constant need for retraining } \\
\text { Cost effective } \\
\text { Time efficient } \\
\text { Traceable skills and knowledge }\end{array}$ & $\begin{array}{l}\text { Knowledgeable employees } \\
\text { Simple, efficient training for } \\
\text { current employees }\end{array}$ \\
\hline Public & $\begin{array}{l}\text { Impact government funding, } \\
\text { legislation } \\
\text { Curiosity }\end{array}$ & $\begin{array}{l}\text { Easy to understand } \\
\text { Readily available } \\
\text { Various age levels }\end{array}$ \\
\hline Students & $\begin{array}{l}\text { Good paying jobs } \\
\text { Transferable skills }\end{array}$ & $\begin{array}{l}\text { Efficient education } \\
\text { Application driven topics and } \\
\text { content }\end{array}$ \\
\hline
\end{tabular}

Table 1. Educational Content User Community

Once your audience has been determined, one good way to get information is to survey potential users. For Dakota County Technical College and the Nano-Link Regional Center creating nanotechnology content, high school and college science teachers provided the initial, primary audience for the resulting content. Over 300 educators were surveyed during a 12 month period to determine the highest priority items for new, emerging technology educational content. The survey results showed that content including hands-on activities and that falling into the "fun" description had the highest priority with $95 \%$ and $85 \%$ respectively of the responders rating these two items in the highest priority range. The next two highest priority items were short duration content (fitting into a 50 minute class period) and connectivity to other disciplines. These two items were rated highly be $65 \%$ and $60 \%$ of the responders respectively. Items that were rated at a lower priority included, stipends for training $(25 \%)$, correlation to standards (30\%), application driven $(25 \%)$ and science rigor (35\%). Educators in general were not particularly interested in detailed presentation or lecture material, detailed technical background information, or test questions and material. What educators wanted was activity driven, time effective examples and experiments for emerging technology (nanoscale science) that they could use to engage students - the educators would determine how to present the scientific content, background and define 
level of difficulty. This response was consistent between high school and college science educators. While high school faculty wanted content that could be tied to traditional science concepts, college educators wanted more application driven or program specific content. Although not included in the survey, all educators are looking for material that includes critical thinking and investigative skills as part of the activity or content.

It is interesting to note that often content creators may not be aware of or may misjudge the priorities and requirements of their user community. Combined data from two curriculum modularization workshops held in 2011 revealed what 31 curriculum developers thought what their customers wanted from the modular curriculum they developed. Many had not asked or surveyed their customers on desirable curriculum characteristics. The workshop attendees were asked to rank a list of 15 items starting with the most important as number 15 . The top five ranked items were used for the summary, provided in Table 2, and provides telling results. Of 15 items, $70 \%$ of the respondents $(n=31)$ ranked item 1 (hands-on, problem based learning) as the most important. For the same group, 55\% ranked item five (hands-on materials) as second most important for their "customers". Third most important was item in the combined results with $49 \%$ ranking it in the top five was that the modules were application driven. The developers overwhelmingly thought fitting material a class period (item three) was the least important item to their customers. The other lowest importance items to the most respondents were that the curriculum be aligned to specific courses that they were teaching and that professional development was provided.

Pre-workshop activity. Please rank the following 15 curriculum attributes, 15 being the most important, 1 being the least important that you believe are important to your customer community.

\section{Priority Results}

1.Hands on/ Problem-based learning

\section{FUN}

3. 1 Class period modules(45-50 minutes)

4.Resource materials ( including multi-media, presentation, assignments, answer keys, activity sheets, material lists)

5.Hand-on materials

6.Alignment table to appropriate courses (mostly STEM, but could be others)

7.Rigorouos Science

8.Application Driven

9.Professional development for implementation (training sessions/detailed "how to"/ seminars/workshops) 10.Professional development for contant

11.Accessible easily( downloadable/free)

12.Alignment to science and/or technology standards

13. Contant assessments

14. Relationships

15.Stipends

Table 2. Results of 31 workshop attendees who were content creators. 
Although the creators, in some cases, matched customer needs, this was not always the case. This lack of coordination between what we (educator content creators) are creating and what our customers (other educators) need may be one of the fundamental reasons for the lack of emerging technology or application driven examples into the classroom.

For example, DCTC spent significant time and effort creating lecture materials to complement the module content. This effort involved obtaining copyright approval for some material, as well as redrawing or creating new content. This was a tedious activity undertaken prior to the survey activity. Based on the survey data and well as the focus groups, lecture material is of moderate importance to the user community. In many cases, educators just plan to use their own lecture material or minimally use that resource. Therefore, time was spent creating material that was not critical for the implementation or integration of the module content in to the classroom. Hence, various user communities, their restrictions and requirements as well as the pace of technology change require new considerations for the creation, organization and dissemination of educational content.

A Module Approach for Emerging Technology Content:

For many reasons, breaking down the required educational content for new or emerging technology into smaller, topical specific units or modules is a favorable approach. First, information can be conveyed in smaller amounts, allowing educators and students to more easily grasp the information. For industry users, they can select only the modules appropriate for training or retraining of employees, rather than spend time on material that may be standard or unnecessary for their specific market segment. Instructors in specific program areas, i.e. photonics or biotechnology, can select appropriate modules and introduce new applicable material in classes without significant disruption to the planned course organization or syllabus. For educators, learning a "modules worth" of new content is less time consuming than trying to assess a large amount of new material and integrate it into an existing format. Figure 1 shows the components of a topical educational module and Table 3 provides a list and status of the modules. The module contents in Figure 1 are based on the results from surveys of high school and secondary educators as well as industry needs data.

Module Table of Contents

\begin{tabular}{lll} 
Team/group work & Prerequisites & \multicolumn{1}{c}{ Experiments } \\
Data Analysis & List of companion & Student Assessment \\
Critical Thinking & traditional concepts & Topics for Discussion \\
Inquiry Learning & Lecture Power Points - & Models, Simulations, \\
Topic specific & Nano Concepts & animations \\
3 to 5 hours of class time & As Appropriate: & Related journal articles and \\
Background information on & Demonstrations & worksheets \\
the topic & Activities &
\end{tabular}

Figure 1. Components of an educational module 
During the last year, 8 activity-based, topical, complete modules have been created and disseminated for use in high school and college classrooms. These modules focus on nanoscale science related to fundamental concepts, chemistry, material science and photonics. The modules, including activities and content are designed to be multi-disciplinary to facilitate the largest potential audience. During the 2012 school year, to date, 9 modules have been distributed to over 85 educators in 18 states, reaching over 6000 students. On a scale of 1 to 5 the average implementation and value rating is 4.3 based on educator responses. We also asked the educator which classes the modules were used in and which of the supporting material was used the most and the least.

Finally, we asked the educators to assess the student understanding of the fundamental concepts conveyed in the modules. These preliminary results are shown in Table 4 below. The data collected to date show that educators are using the content in many different classes, validating the multi-disciplinary goal of the modules. The data also shows that educators do not use the lecture materials (slide materials) as expected based on the initial surveys and that educators believe that students understand the concepts intended for the modules The educators were asked 2 questions in the survey with regard to student understanding and grasp of the major module concepts. The methods by which the educators determined their response is unknown. Overall, educators responded that $50 \%$ of the students understood 50 or greater percentage of the content. The table presents the results for the percentage of students that understood 75 to $100 \%$ of the intended module content. In order to better understand how and for which student population the modules increased student learning additional data and research is required. . Additional surveys and/or educator focus groups or face to face interviews will be used to determine if a level of improvement in understanding has been achieved or which approaches may be employed to improve this aspect of the modules. 


\begin{tabular}{|c|c|c|c|c|c|}
\hline Module & Focus & $\begin{array}{c}\text { Traditional } \\
\text { Sciences }\end{array}$ & Nano Concept & $\begin{array}{l}\text { Application } \\
\text { Correlation } \\
\end{array}$ & Status \\
\hline Effervescent Tablets & $\begin{array}{c}\text { Surface area to volume } \\
\text { ratio }\end{array}$ & $\begin{array}{l}\text { Algebra and } \\
\text { graphing }\end{array}$ & $\begin{array}{l}\text { Reactivity and } \\
\text { surface area }\end{array}$ & $\begin{array}{c}\text { Batteries, } \\
\text { catalytic } \\
\text { converters }\end{array}$ & $\begin{array}{l}\text { Complete and } \\
\text { distributed }\end{array}$ \\
\hline Magic Sand & Superhydrophobicity & $\begin{array}{l}\text { Chemistry } \\
\text { Physics }\end{array}$ & $\begin{array}{l}\text { Priorities of } \\
\text { Forces and } \\
\text { Interactions }\end{array}$ & $\begin{array}{c}\text { Water } \\
\text { purification }\end{array}$ & $\begin{array}{l}\text { Complete and } \\
\text { distributed }\end{array}$ \\
\hline Crystals Part 1 & Self Assembly & $\begin{array}{c}\text { Physics } \\
\text { Chemistry } \\
\end{array}$ & $\begin{array}{l}\text { Material } \\
\text { structure }\end{array}$ & Critical thinking & $\begin{array}{c}\text { Complete and } \\
\text { distributed }\end{array}$ \\
\hline Crystals Part 2 & Unit Cells & $\begin{array}{l}\text { Material } \\
\text { Science }\end{array}$ & $\begin{array}{l}\text { Material } \\
\text { structure }\end{array}$ & Material structure & $\begin{array}{c}\text { In process } \\
(3 / 13)\end{array}$ \\
\hline Cross-Link Polymer & $\begin{array}{l}\text { Fluid and polymer } \\
\text { interactions }\end{array}$ & $\begin{array}{l}\text { Chemistry } \\
\text { Biology }\end{array}$ & $\begin{array}{l}\text { Priorities of } \\
\text { Forces and } \\
\text { Interactions }\end{array}$ & Drug delivery & $\begin{array}{l}\text { Complete and } \\
\text { distributed }\end{array}$ \\
\hline Ring-Polymer & $\begin{array}{l}\text { Fluid and polymer } \\
\text { interactions }\end{array}$ & Chemistry & $\begin{array}{l}\text { Priorities of } \\
\text { Forces and } \\
\text { Interactions }\end{array}$ & $\begin{array}{c}\text { Absorbent } \\
\text { material }\end{array}$ & $\begin{array}{l}\text { Complete and } \\
\text { distributed }\end{array}$ \\
\hline Magic Fish & Scientific Method & General & General & $\begin{array}{c}\text { Design of } \\
\text { experiments }\end{array}$ & $\begin{array}{c}\text { Complete and } \\
\text { distributed }\end{array}$ \\
\hline Sunscreen & $\begin{array}{l}\text { Nano particles and light } \\
\text { interaction }\end{array}$ & Physics & $\begin{array}{l}\text { Size dependent } \\
\text { interactions }\end{array}$ & Sunscreen & In beta test \\
\hline Thin Films & Interaction with light & Physics & $\begin{array}{l}\text { Size dependent } \\
\text { interactions }\end{array}$ & $\begin{array}{l}\text { Decorative } \\
\text { products }\end{array}$ & $\begin{array}{l}\text { Complete and } \\
\text { distributed }\end{array}$ \\
\hline Memory Metals & $\begin{array}{c}\text { Crystalline structure of } \\
\text { metals }\end{array}$ & $\begin{array}{l}\text { Physics } \\
\text { Material } \\
\text { Science }\end{array}$ & $\begin{array}{l}\text { Nanoscale } \\
\text { properties }\end{array}$ & Springs & Distributed \\
\hline $\begin{array}{c}\text { Light Emitting Diodes } \\
\text { Part } 1\end{array}$ & $\begin{array}{l}\text { Energy band structure } \\
\text { Energy and wavelength }\end{array}$ & Physics & $\begin{array}{c}\text { Quantum at the } \\
\text { nanoscale }\end{array}$ & $\begin{array}{l}\text { Energy efficient } \\
\text { lighting }\end{array}$ & $\begin{array}{c}\text { In beta test } \\
(2 / 13)\end{array}$ \\
\hline $\begin{array}{l}\text { Light Emitting Diodes } \\
\text { Part } 2\end{array}$ & Device operation & Physics & $\begin{array}{l}\text { Quantum at the } \\
\text { nanoscale }\end{array}$ & Solid state & $\begin{array}{c}\text { In process } \\
(3 / 13)\end{array}$ \\
\hline $\begin{array}{l}\text { What's wrong with } \\
\text { this picture? }\end{array}$ & Atomic Structure & Physics & $\begin{array}{c}\text { Atomic } \\
\text { structure }\end{array}$ & $\begin{array}{c}\text { Geckos and } \\
\text { Jumping spiders }\end{array}$ & $\begin{array}{c}\text { In beta test } \\
(2 / 13)\end{array}$ \\
\hline Water and Salt & $\begin{array}{c}\text { Dissolving process } \\
\text { Temperature dependence }\end{array}$ & Chemistry & Sense of Scale & $\begin{array}{c}\text { Supersaturated } \\
\text { solutions }\end{array}$ & $\begin{array}{c}\text { In beta test } \\
(2 / 13)\end{array}$ \\
\hline $\begin{array}{c}\text { Micelles: Biology and } \\
\text { Soap }\end{array}$ & $\begin{array}{l}\text { Non uniform charge } \\
\text { distribution Non }\end{array}$ & Biology & $\begin{array}{c}\text { Hydrophobic } \\
\text { and } \\
\text { hydrophilic }\end{array}$ & Detergent & $\begin{array}{c}\text { In process } \\
(3 / 13)\end{array}$ \\
\hline Protein Folding & $\begin{array}{c}\text { Non uniform charge } \\
\text { distribution }\end{array}$ & Biology & $\begin{array}{c}\text { Molecular } \\
\text { structure }\end{array}$ & Drug interactions & $\begin{array}{l}\text { In process } \\
(3 / 13)\end{array}$ \\
\hline Micro Fluidics & $\begin{array}{l}\text { Mixing fluids (turbulent } \\
\text { and lamiar plow) }\end{array}$ & $\begin{array}{l}\text { Physics } \\
\text { Material } \\
\text { science }\end{array}$ & $\begin{array}{l}\text { Phenomena at } \\
\text { the nanoscale }\end{array}$ & Lab on a Chip & $\begin{array}{c}\text { In beta test } \\
(2 / 13)\end{array}$ \\
\hline $\begin{array}{c}\text { Carbon Nanotubes } \\
\text { Part } 1\end{array}$ & $\begin{array}{c}\text { Material Properties - } \\
\text { Strength }\end{array}$ & $\begin{array}{l}\text { Material } \\
\text { Science }\end{array}$ & $\begin{array}{l}\text { Molecular } \\
\text { structures }\end{array}$ & Automobiles & $\begin{array}{c}\text { In process } \\
(3 / 13)\end{array}$ \\
\hline Diffraction Gratings & Optics as sensors & Physics & $\begin{array}{l}\text { Size dependent } \\
\text { interactions }\end{array}$ & Sensors & $\begin{array}{c}\text { In process } \\
(5 / 13)\end{array}$ \\
\hline $\begin{array}{c}\text { Nanoparticles in } \\
\text { Solution }\end{array}$ & Diffusion & Chemistry & $\begin{array}{c}\text { Molecular } \\
\text { interactions }\end{array}$ & Targeted systems & $\begin{array}{c}\text { In process } \\
(5 / 13)\end{array}$ \\
\hline
\end{tabular}

Table 3. Emerging Technology Modules 


\begin{tabular}{|c|c|c|c|c|}
\hline Module topic & $\begin{array}{l}\text { Subjects the activity } \\
\text { was used in }\end{array}$ & $\begin{array}{l}\text { Percentage of students } \\
\text { that understood over } \\
75 \% \text { of the intended } \\
\text { concepts - Based on } \\
\text { educators response to } \\
\text { two content specific } \\
\text { questions }\end{array}$ & $\begin{array}{l}\text { Most used } \\
\text { supporting module } \\
\text { content }\end{array}$ & $\begin{array}{l}\text { Least Used } \\
\text { supporting module } \\
\text { content }\end{array}$ \\
\hline $\begin{array}{l}\text { Super- } \\
\text { hydrophobicity }\end{array}$ & $\begin{array}{l}38.5 \% \text { - Chemistry } \\
23.1 \% \text { - Technology } \\
15.4 \% \text { - Biology } \\
23.1 \% \text { - Physics } \\
7.7 \% \text { - Engineering } \\
\text { and math }\end{array}$ & 47.1 & $\begin{array}{l}\text { - Teacher: Guided } \\
\text { Inquiry } \\
\text { - Teacher: Module } \\
\text { Guide } \\
\text { - Explain: Discussion } \\
\text { Questions }\end{array}$ & $\begin{array}{l}\text { - Teacher } \\
\text { Introduction: } \\
\text { Middle school } \\
\text { - Explain: Quiz sheet } \\
\text { - Engage: Ppt }\end{array}$ \\
\hline Polymers & $\begin{array}{l}27.3 \% \text { - Chemistry } \\
45.5 \% \text { - Technology } \\
18.2 \% \text { - Biology } \\
9.1 \% \text { - Physics } \\
9.1 \% \text { - Engineering }\end{array}$ & 45.5 & $\begin{array}{l}\text { - Polymers } \\
\text { experiment lab steps } \\
\text { - General Discussion } \\
\text { questions } \\
\text { - Video: Ring } \\
\text { polymers }\end{array}$ & $\begin{array}{l}\text { - Polymers PPT } \\
\text { slides } \\
\text { - Discussion } \\
\text { questions for PPT } \\
\text { - Video: Cross-linked } \\
\text { Polymers }\end{array}$ \\
\hline Crystals & $\begin{array}{l}\text { 66.7\% - Chemistry } \\
33.3 \% \text { - Technology } \\
33.3 \% \text { - Biology } \\
33.3 \% \text { - Physics }\end{array}$ & 60 & $\begin{array}{l}\text { - Crystals Guide Part } \\
1 \\
\text { - Video: How to make } \\
\text { hot ice! Crazy! } \\
\text { - Video: Fun with } \\
\text { sodium acetate }\end{array}$ & $\begin{array}{l}\text { - Crystals power } \\
\text { point slides } \\
\text { - Discussion } \\
\text { questions for Ppt } \\
\text { - Video: Super } \\
\text { saturated sodium } \\
\text { acetate (slow } \\
\text { crystallization) }\end{array}$ \\
\hline
\end{tabular}

Table 4. Partial Summary of Initial Modules Use Surveys from Educators

Modular approach to making STEM connections

In 2000, secondary STEM teachers Florida noted that resource materials available to them were limited in making connections between science and math content and high technology and emerging technology applications. To address this need, educational resource materials were developed to impact the decisions of high school and community college students to follow technology and science career paths. The High School Technology Initiative (HSTI) project worked closely with STEM faculty from the University of South Florida College of Engineering and Hillsborough Community College and a core team of teachers in Tampa Bay to define the module characteristics to be used. The teacher team defined where there were existing gaps in support materials; what formats teachers would and could use in classrooms; as well as ancillary materials that teachers would want to make the module insertion into a course as "seamless" as possible. The teacher core also continuously worked to keep the level of the materials consistent as well as appropriate for their students. 
All HSTI modules were built around some common technologies where the science and mathematics multiple levels were desired and produced for many concepts beginning with introductory and qualitative versions that could be used in ninth grade science, technology and math courses. Materials on the same topic were also developed to meet the needs of older and more advanced students. These increased the intensity of the mathematics and depth of the science concepts around the same topic and related to the same technology. Therefore, a particular module in any unit is related to many others, and a lot of the materials are visually connected by repeated use of the same video or images. The materials are intended to complement the teacher's current text based content and blend into existing or slightly modified lesson plans.

The chart below (Table 5) highlights the technology focal points in the HSTI modules on the Atom and Problem Solving as well as the secondary science and math topics that they are directly related to.

\begin{tabular}{|c|c|c|}
\hline Technology & High School Science Topics & High School Math Topics \\
\hline \multicolumn{3}{|l|}{ ATOM MODULE } \\
\hline $\begin{array}{l}\text { LED (light } \\
\text { emitting diodes) }\end{array}$ & $\begin{array}{l}\text { Electronic structure; transitions; } \\
\text { wave particle relationships; } \\
\text { quantized energy; spectroscopy }\end{array}$ & $\begin{array}{l}\text { Simple and complex algebraic } \\
\text { equations; inverse power } \\
\text { functions }\end{array}$ \\
\hline $\begin{array}{l}\text { X-Ray and CAT } \\
\text { Scans }\end{array}$ & $\begin{array}{l}\text { Electronic structure; transitions; } \\
\text { wave particle relationships; } \\
\text { quantized energy; spectroscopy }\end{array}$ & $\begin{array}{l}\text { Simple and complex algebraic } \\
\text { equations; inverse power } \\
\text { functions; }\end{array}$ \\
\hline Food Irradiation & $\begin{array}{l}\text { Properties of nuclear particles } \\
\text { (gamma rays); balance equations }\end{array}$ & $\begin{array}{l}\text { Algebraic arithmetic and balance } \\
\text { equations }\end{array}$ \\
\hline Carbon Dating & $\begin{array}{l}\text { Properties of nuclear particles } \\
\text { (beta particles) }\end{array}$ & Exponential functions (half life) \\
\hline Smoke Detection & $\begin{array}{l}\text { Properties of nuclear particles } \\
\text { (alpha particles) }\end{array}$ & Algebraic manipulations \\
\hline \multicolumn{3}{|c|}{ PROBLEM SOLVING MODULE } \\
\hline $\begin{array}{l}\text { Semiconductor } \\
\text { Fabrication } \\
\text { Processes }\end{array}$ & $\begin{array}{l}\text { Balance chemical reactions; } \\
\text { atomic structure; states of matter }\end{array}$ & $\begin{array}{l}\text { Algebraic manipulations; } \\
\text { geometry; significant figures; } \\
\text { exponential notation; problem } \\
\text { solving }\end{array}$ \\
\hline
\end{tabular}

Table 5. HSTI Modules

In a nation-wide survey near the end of the project, $74.5 \%$ of respondents sampled from the over 300 teachers participating in HSTI professional training, felt that their students do not or only 
sometimes make the connection between science, technology, and the objects they encounter in everyday life and these modules could help them make those connections while reinforcing basic STEM principles. Other results from this sample include demographic data and revealed that these modules were being used to impact the education of at least 2,819 students annually. These modules cover the mathematics and science linkages to, for example, semiconductor manufacturing, medical diagnostic equipment, food processing, solid state lighting and safety technologies. On a statistical basis, the same teacher survey participants strongly agreed with the statement that "HSTI materials helped my students to see the connections between science, math and technology."

\section{Conclusions}

The success of content modularization for these two applications supports this strategy for curriculum development for connecting topics via underlying principles as well as for introducing emerging technologies. Both approaches require integrating science, technology, engineering and math (STEM) concepts via technology applications. For first introductions, the presentation of the materials should make a strong connection to the targeted technology at a fundamental level that can be presented in such a way that students do not get overwhelmed with the foundational piece. The presentations should have visual aids making the connection between the technology and the STEM foundations. The modules should be in stackable packets that can be cut off at any time, depending on the time available in a particular class or audience. For secondary audiences, use of the required standards to find good connection points that might be obvious to the experienced subject matter expert. There are many adages that say and much documented research that most students and adults learn best by doing, so keep hands-on, problem-based learning as part of the models to modularize curriculum.

Acknowledgements:

The authors wish to acknowledge and thank the National Science Foundation Advanced Technology Education Program for support of these activities.

Bibliography:

1. Barger, M., Gilbert, R., Hoff, A., Roe, E., Hickey, J., “Technology Applications for High School Mathematics and Science Curriculum",Proceedings of the 2004 American Society for Engineering Education Annual Conference \& Exposition. ASEE, 2004.

2. Hoff, A., Barger, M., Hickey, J., Rogers, K., Gilbert, R., Roe, E., McCullough, E., “Teaching Problem Solving To High School And Community College Students: A New Approach",Proceedings of the 2001 American Society for Engineering Education Annual Conference \& Exposition. ASEE, 2001. 
3. Hoff, A., Barger, M., Hickey, J., Rogers, K., Gilbert, R., Roe, E., “ Content Generation: Lessons Learned from a Successful High School Science and Mathematics Outreach Program",Proceedings of the 2003 American Society for Engineering Education Annual Conference \& Exposition. ASEE, 2003.

4. 2. Andrew Hoff, M. Barger, R. Gilbert, K. Rogers, J. Hickey, E. Roe. "High Technology Focused Curriculum Materials for High School Science Instruction", Proceedings of the 2000 American Society for Engineering

Education Annual Conference \& Exposition. ASEE, 2000.

5. Eric Roe, M. Barger, A. Hoff, R. Gilbert, J. Hickey, K. Rogers, A. Greenway, M. Hepburn, K. Loweke, B. Smrstick. "High School Technology Initiative (HSTI): High Tech Curriculum Materials for High School Science", Seventh Annual Conference - Advanced Technological Education in SemiconductorManufacturing. ATESM, 2001. 